\title{
Antioxidant and anticancer effects of fermented Rhus verniciflua stem bark extracts in HCT-116 cells
}

\author{
Myeong-ok Kim ${ }^{\mathrm{a}}$, Jinfeng Yang ${ }^{\mathrm{b}}$, Yong Soo Kwon ${ }^{\mathrm{c}}$, Myong Jo Kim ${ }^{\mathrm{a}, *}$ \\ a Department of Applied Plant Sciences, Kangwon National University, Chuncheon 200-701, \\ Republic of Korea \\ b Bioherb Research Institute, Kangwon National University, Chuncheon 200-701, Republic of Korea \\ c Department of Pharmacy, Kangwon National University, Chuncheon 200-701, Republic of Korea
}

*Corresponding author, e-mail: kimmjo@kangwon.ac.kr

Received 16 Jan 2015

Accepted 22 Aug 2015

\begin{abstract}
Rhus verniciflua bark has been used as a traditional medicine for the treatment of several diseases in Korea. In this study, the antioxidant properties and anticancer activity of a fermented $R$. verniciflua (F-RV) methanol extract and its fractions were determined. The methanol extract and the ethyl acetate fraction had high radical-scavenging and reducing-power activities, higher than that of butylated hydroxytoluene. Moreover, the antioxidant activity was correlated with the contents of the phenolic compounds. The cell viability assay showed that F-RV contains anticancer activity in a colon cancer cell line (HCT-116), and upregulates TGF- $\beta$. Thus F-RV has an inhibitory effect on cell proliferation and can induce apoptosis and senescence. F-RV could be useful for the development of bioactive food and anticancer drugs.
\end{abstract}

KEYWORDS: colon cancer, flavonoid, Toxicodendron vernicifluum, sonic hedgehog pathway

\section{INTRODUCTION}

Reactive oxygen species (ROS) are free radicals such as hydroxyl radicals, superoxide radicals, and hydrogen peroxide. Their oxidative effects have been implicated in inflammation and cancer development. Natural antioxidants such as polyphenols, flavonoids, anthocyanidin, ascorbic acid, tocopherol, and anthocyanin can reduce ROS effects in the body ${ }^{1,2}$. Antioxidants decrease oxygen concentration by scavenging initial radicals, binding to metal ion catalysts, decomposing primary products to active compounds, and chain breaking to prevent continued hydrogen abstraction.

Rhus verniciflua (RV) is a well-known lacquer tree indigenous to East Asian countries ${ }^{3}$. The main lacquer compound, urushiol, is toxic and can cause contact dermatitis. Previous reports have however revealed that fermentation reduces the urushiol. The fermented preparation (referred to as F-RV) has various in vitro and in vivo biological activities such as antioxidant, anticancer, and anti-inflammatory. F-RV inhibits $\alpha$-glucosidase, protects against carbon tetrachloride-induced liver injury in mice, and has anti-platelet, anti-mutagenic, and anti-nociceptive effects $^{4-6}$. In this paper, we investigated the antioxidant activity of F-RV and its association with the anticancer signalling pathway.

\section{MATERIALS AND METHODS}

Fermented $R$. verniciflua stem bark extract and fractions

Fermented $R$. verniciflua (F-RV) was provided by the Rural Development Administration, Republic of Korea, in June 2014. F-RV (916.4 g) was crushed to powder and heated under reflux at $65^{\circ} \mathrm{C}$ for $2 \mathrm{~h}$ with 11 methanol. The extract was filtered (Filter paper, Advantec, circles $300 \mathrm{~mm}$, Japan), and the solvent evaporated at $45^{\circ} \mathrm{C}$ using a rotary evaporator. The sample was dissolved in water, and extracted with $n$-hexane. The remaining aqueous fraction was extracted with ethyl acetate, and then with $n$-butanol, and each fraction was concentrated using a vacuum evaporator.

\section{Radical scavenging activity}

The free radical scavenging activity of each F-RV fraction, butylated hydroxyanisole (BHA), and butylated hydroxytoluene (BHT) was assayed using a stable free radical, 1,1-diphenyl-2-picrylhydrazyl (DPPH). The reaction mixture contained $1 \mathrm{ml}$ of $0.15 \mathrm{mM}$ DPPH $(59.148 \mathrm{mg} / \mathrm{l}$ in $100 \%$ methanol) and $4 \mathrm{ml}$ of $100 \%$ methanol and the extract or fraction at various concentrations. The reaction mixture was allowed to stand for $30 \mathrm{~min}$ at room 
temperature and the radical scavenging activity of each antioxidant was quantified by decolourization at $517 \mathrm{~nm}$. The $\mathrm{RC}_{50}$ value $(\mathrm{mg} / \mathrm{ml})$ is the concentration at which the scavenging activity is $50 \%$.

\section{Reducing power}

The reducing power was measured using a standard method for compounds with antioxidant activity. Extracts or fractions $(0.01,0.1$, and $1.0 \mathrm{mg} / \mathrm{ml}$ ) were prepared in $80 \%$ methanol. For each sample solution, $100 \mu \mathrm{l}$ was mixed with $500 \mu \mathrm{l}$ of $0.2 \mathrm{M}$ $\mathrm{Na}_{3} \mathrm{PO}_{4}$ buffer ( $\mathrm{pH} 6.6$ ) and $500 \mu \mathrm{l}$ of $1 \%$ potassium ferricyanide. The reaction mixture was allowed to stand for $20 \mathrm{~min}$ in a $50^{\circ} \mathrm{C}$ water bath, then $2.5 \mathrm{ml}$ of $10 \%$ trichloroacetic acid was added. The mixture was left for $10 \mathrm{~min}$ at room temperature, then a $500 \mu \mathrm{l}$ aliquot was mixed with $500 \mu \mathrm{l}$ of water and $100 \mu \mathrm{l}$ of $1 \% \mathrm{FeCl}_{3}$ and the absorbance was measured at $700 \mathrm{~nm}$.

\section{Total phenolic and total flavonoid contents}

The total phenolic content of the extracts was measured by Folin-Ciocalteu method. For the study of total phenolic content, each extract fraction $(1.0 \mathrm{mg} / \mathrm{ml})$ was prepared in water. The sample $(100 \mu \mathrm{l})$ was added to $50 \mu \mathrm{l}$ of $2 \mathrm{~N}$ Folin-Ciocalteu reagent and mixed for $3 \mathrm{~min}$. After $300 \mu \mathrm{l}$ of $20 \%$ $\mathrm{Na}_{2} \mathrm{CO}_{3}$ was added, the reaction mixture was left for $30 \mathrm{~min}$. Finally, $1 \mathrm{ml}$ water was added and the absorbance was measured at $725 \mathrm{~nm}$. All measurements were conducted in triplicate, and based on the calibration curve for gallic acid. The data were expressed as gallic acid equivalents per $\mathrm{mg}$ of the extract.

The total flavonoid content of the extract and fractions was measured as previously described. For the measurement of total flavonoid content, each extract fraction $(1.0 \mathrm{mg} / \mathrm{ml})$ was prepared in $80 \%$ ethanol. The sample $(100 \mu \mathrm{l})$ was added to $900 \mu \mathrm{l}$ of $80 \%$ ethanol, and then aliquot of $500 \mu \mathrm{l}$ was mixed with $100 \mu \mathrm{l}$ of $10 \% \mathrm{Al}\left(\mathrm{NO}_{3}\right)_{3}, 100 \mu \mathrm{l}$ of $1 \mathrm{M}$ potassium acetate, and $4.3 \mathrm{ml}$ of $80 \%$ ethanol. The reaction mixture was allowed to stand for $40 \mathrm{~min}$ at room temperature, and then the absorbance was measured at $415 \mathrm{~nm}$. All measurements were conducted in triplicate and the data were expressed as the amount of quercetin (in $\mathrm{g}$ ) per $\mathrm{kg}$ of the extract based on the calibration curve for quercetin.

\section{Cell culture}

The human colon cancer cell line HCT-116 was cultured in RPMI 1640 medium that contained 10\% foetal bovine serum (FBS), 2 mM L-glutamine, and
100 units/ml penicillin and streptomycin. The cells were maintained at $37^{\circ} \mathrm{C}$ in an incubator under $5 \%$ $\mathrm{CO}_{2}$.

\section{Cell proliferation assay}

Cell proliferation was measured by a colorimetric WST-1 cell viability assay (Takara, Japan). Cells $\left(1 \times 10^{5}\right.$ per well) were exposed to various concentrations $(0.1,1$, and $10 \mu \mathrm{g} /$ well $)$ of the samples or cisplatin (as a positive control) in 96well sterile plastic plates (Costar, New York). After incubation at $37^{\circ} \mathrm{C}$ for $24 \mathrm{~h}, 2$-(4-iodophenyl)-3-(4nitrophenyl)-5-(2,4-disulfophenyl)-2H-tetrazolium monosodium salt (WST-1) reagent $(10 \mu \mathrm{g} /$ well) was added. After incubation at $37^{\circ} \mathrm{C}$ for $4 \mathrm{~h}$, cell counts were determined by an ELISA reader multilabel counter (Wallac VICTOR ${ }^{2}$, Japan) at wavelength of $450 \mathrm{~nm}$. The final concentration of dimethyl sulphoxide (DMSO) in the cell samples was less than $0.1 \%$.

\section{Wound healing assay}

Cells were cultured in 24-well plates at $1 \times 10^{4}$ cells/well in medium supplemented with $10 \%$ foetal bovine serum (FBS) and 1\% antibiotics (penicillin and streptomycin, $100 \mathrm{U} / \mathrm{ml}$ ). The cells were incubated in the absence of serum for $24 \mathrm{~h}$ and wounded in a line across the well with a $200-\mu 1$ standard pipette tip. The wounded cells were then washed twice with phosphate buffered saline (PBS) followed by serum-free media supplemented with $10 \%$ FBS and $1 \%$ antibiotics (penicillin and streptomycin, $100 \mathrm{U} / \mathrm{ml}$ ) to remove cell debris. The medium was removed and fresh growth medium containing one of the F-RV fractions or cisplatin (as a positive control) $(10 \mu \mathrm{g} / \mathrm{ml})$ was added. After incubation at $37^{\circ} \mathrm{C}$ for $24 \mathrm{~h}$, the plates were washed twice with PBS followed by methanol for $10 \mathrm{~min}$, and then dried. Cells were then stained with $0.05 \%$ GIEMSA in water and dried. The plates were examined using a camera connected to an inverted microscope (Inverted Microscope AE 31, Motic, China) at $100 \times$ magnification.

\section{Invasion and morphology}

Cells were cultured in 6-well plates at $1 \times 10^{4}$ cells/ well in medium supplemented with $10 \%$ FBS and $1 \%$ antibiotics (penicillin and streptomycin, $100 \mathrm{U} / \mathrm{ml}$ ). The cell invasion assay was performed using a probe according to the manufacturer's protocol with a BD invasion kit (BD Biosciences, Chicago, IL, USA). The morphology was determined using a camera connected to an inverted microscope at 
$100 \times$ magnification. For the cell morphology assay, cells were incubated in the absence of serum for $24 \mathrm{~h}$ and then treated with an F-RV fraction. After incubation at $37^{\circ} \mathrm{C}$ for $24 \mathrm{~h}$, they were stained with $0.05 \%$ GIEMSA in water and then dried. The morphology was determined using camera connected to an inverted microscope at $400 \times$ magnification.

\section{Measurement of apoptosis by fluorescence activated cell sorting (FACS)}

Fluorescence activated cell sorting (FACS) was performed using an apoptosis signal probe according to the manufacturer's protocol with an FITC Annexin V Apoptosis detection kit II (BD Biosciences, Chicago, IL, USA). Briefly, the fixed cells were pretreated for $10 \mathrm{~min}$ in $70 \%$ ethanol at room temperature. Analysis was performed by measuring fluorescein isothiocyanate (FITC) and propidium iodide.

\section{Western blot analysis}

The effect of F-RV in inducing senescence, apoptosis and the hedgehog pathway was evaluated by FACS and Western blot analyses. Cell lysates were prepared by adding $20 \mu \mathrm{l}$ RIPA lysis buffer (Cell signalling) to the cell cultures. Proteins were separated on $12 \%$ SDS-polyacrylamide gels and were electrotransferred to PVDF membranes (Millipore, Bedford, MA, USA), then rinsed with $100 \%$ methanol. Antibodies were obtained from the following sources: caspase-8, caspase- 9 , and sonic hedgehog (shh) were purchased from Cell Signalling Technology (Beverly, MA); Bcl2, p21, p53, $\beta$-actin, patched, smoothened (SMO), Su(Fu), Gli1, and Gli2 were obtained from Santa Cruz Biotechnology (Santa Cruz, CA); and Bak was obtained from Abcam (Abcam, Cambridge, MA). Detection of specific proteins was carried out with an enhanced chemiluminescence assay. SMO and control siRNA (Santa Cruz, CA) were measured according to the manufacturer's instructions using Lipofectamine 2000 (Invitrogen, Carlsbad, CA). Apoptosis was shown by detection of caspase-8, caspase-9, Bcl-2, and Bak. Senescence was shown by p21 and p53, and hedgehog pathway activation was shown by shh, patched, SMO, Su(Fu), Gli1, and Gli2.

\section{Measurement of cytokine in HCT-116 cell lysate}

HCT-116 cells were cultured with F-RV extract or fraction $(20 \mu \mathrm{g} /$ well $)$ and the production of 10 cytokines was assayed with an array of cytokine antibodies. The expression profile of the 10 different cytokines was determined using a RayBio human cytokine array V (RayBiotech) according to the manufacturer's instructions.

\section{Statistical analysis}

Data are expressed as mean $\pm S D$ of the values. Statistical significance was determined by ANOVA. Duncan's multiple range tests were used to determine the significance of differences between the groups. A level of $p<0.05$ was considered to be significant.

\section{RESULTS AND DISCUSSION}

\section{Radical scavenging assay}

Free radical scavenging protects cells from oxidation damage. Fig. 1a shows the DPPH radical scavenging activity of the F-RV extract and fractions BHA and BHT. The methanol extract $\left(\mathrm{RC}_{50}=2.9 \pm 0.0 \mu \mathrm{g} / \mathrm{ml}\right)$ had the highest DPPH radical scavenging activity, followed by the ethyl acetate fraction $\left(\mathrm{RC}_{50}=3.6 \pm 0.0 \mu \mathrm{g} / \mathrm{ml}\right)$ and then BHA $\left(\mathrm{RC}_{50}=4 \pm 1 \mu \mathrm{g} / \mathrm{ml}\right)$ and BHT $\left(\mathrm{RC}_{50}=86.0 \pm 1.5 \mu \mathrm{g} / \mathrm{ml}\right)$. The DPPH radical scavenging activity of the F-RV fractions showed the following descending order: methanol extract $>$ ethyl acetate fraction $>$ butanol fraction $\left(\mathrm{RC}_{50}=5.3 \pm 0.0 \mu \mathrm{g} / \mathrm{ml}\right)>$ water fraction $\left(\mathrm{RC}_{50}=\right.$ $36.3 \pm 0.4 \mu \mathrm{g} / \mathrm{ml})>n$-hexane fraction $\left(\mathrm{RC}_{50}=\right.$ $38.6 \pm 1.1 \mu \mathrm{g} / \mathrm{ml}$ ). Reynertson reported a good linear correlation between total phenolic and DPPH antioxidant capacity ${ }^{7}$. The conclusions were in agreement with Rosana et al, who reported that the antioxidant potential of camu fruit, relates to its phenolic contents ${ }^{8}$. From the above, these results suggest that the antioxidant capacity is correlated with phenolic compounds. Thus the methanol extract has a strong DPPH radical scavenging activity.

\section{Reducing power}

In this assay, the antioxidant activity of the extracts on $\mathrm{Fe}^{3+}$ from $\mathrm{FeCl}_{3}$ was determined. The reducing power was determined using a modified $\mathrm{Fe}^{3+}$ to $\mathrm{Fe}^{2+}$ reduction assay (Fig. 1b). The methanol extract $(1 \mathrm{mg} / \mathrm{ml})$ had the highest reducing power $\left(\mathrm{OD}_{700}=0.56\right)$ among the extract and fractions. The reducing power was significantly correlated with the DPPH radical scavenging activity. The reducing power of the fractions showed the following descending order: methanol extract $>$ ethyl acetate fraction $\left(\mathrm{OD}_{700}=0.50\right)>$ butanol fraction $\left(\mathrm{OD}_{700}=0.36\right)>n$-hexane fraction $\left(\mathrm{OD}_{700}=\right.$ $0.12)>$ water fraction $\left(\mathrm{OD}_{700}=0.08\right)$. BHA and BHT $(1 \mathrm{mg} / \mathrm{ml})$ were used as positive controls 

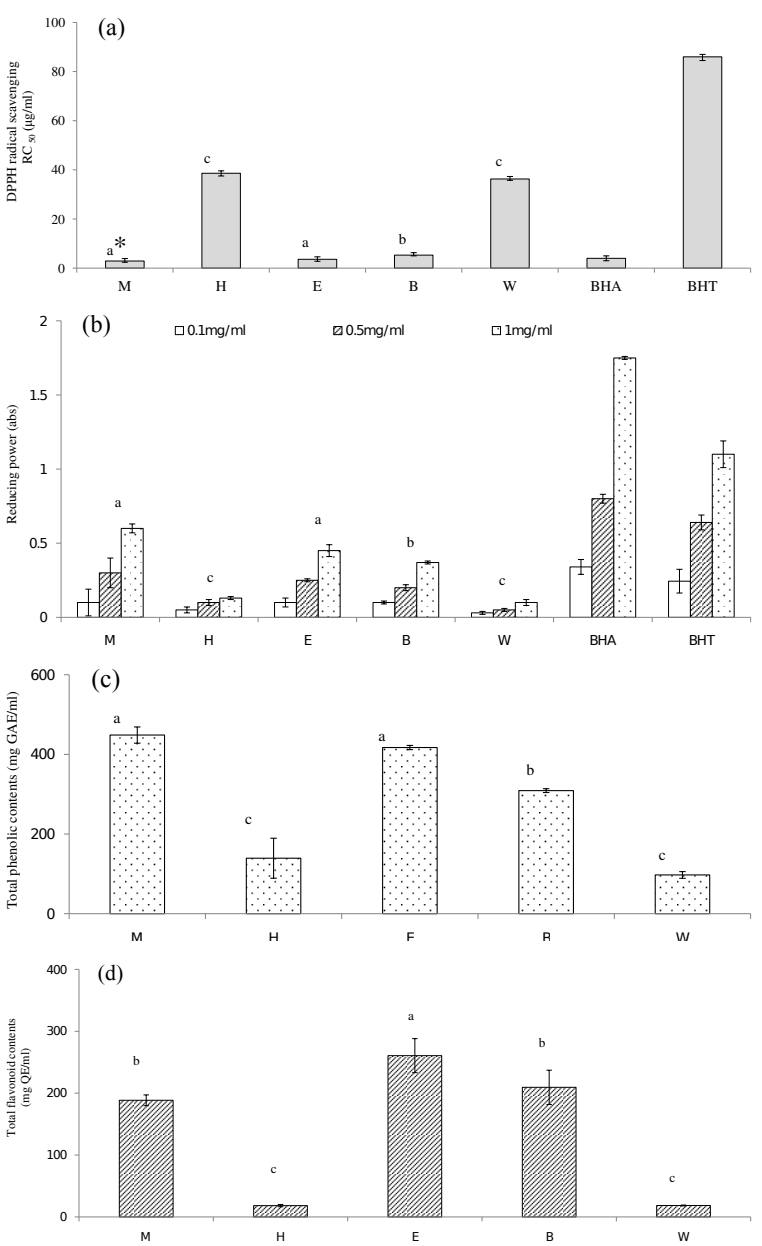

Fig. 1 Comparison of antioxidant activities: (a) DPPH radical scavenging assay; (b) reducing power; (c) total phenolic content based on the calibration curve of gallic acid; (d) total flavonoid content based on the calibration curve of quercetin. M: methanol extract, $\mathrm{H}$ : $n$-hexane fraction, E: ethyl acetate fraction, B: butanol fraction, W: water fraction of F-RV. Values within the same panel marked by a different letter are significantly different at $p<0.05$ by DMRT.

and showed reducing power of $\mathrm{OD}_{700}=1.76$ and $\mathrm{OD}_{700}=1.04$, respectively. A concentration dependent activity increases reducing power induced oxidation decrease was observed ${ }^{9,10}$. The methanol extract and the ethyl acetate fraction showed both strong antioxidant activity and strong DPPH radical scavenging capacity.

\section{Total phenolic and total flavonoid contents}

The total phenolic and total flavonoid contents of various extract fractions were compared with the gallic acid (GAE) content (Fig. 1). Phenolic com- pounds have been shown to have antioxidant activity ${ }^{11}$. The total phenolic and flavonoid contents were significantly higher in the methanol extract and the ethyl acetate fraction than in the other fractions. The methanol extract had the highest phenolic content (GAE $448 \pm 20 \mathrm{mg} / \mathrm{ml}$ ), followed by the ethyl acetate fraction (GAE $417.2 \pm 5.3 \mathrm{mg} / \mathrm{ml}$ ). The phenolic content was significantly correlated with DPPH radical scavenging and reducing power. The flavonoid content of the methanol extract $(\mathrm{QE}$ $188.5 \pm 8.7 \mathrm{mg} / \mathrm{ml}$ ) and ethyl acetate fraction (QE $261 \pm 28 \mathrm{mg} / \mathrm{ml}$ ) was also very high. Unlike the antioxidant activities, however, the flavonoid content was not significantly different from that of the butanol fraction (QE $261 \pm 28 \mathrm{mg} / \mathrm{ml}$ ). Antioxidant activities may be affected by the phenolic content of the plant chemical compounds. The association between antioxidant activities and phenolic compounds has been studied extensively. Natural phenolic compounds from many plants show scavenging activity against free radicals. Studies of $R$. verniciflua have shown that antioxidant activities are present in many compounds such as gallic acid, quercetin, fustin, fiestine, butein, and sulphuretin ${ }^{5}$. Antioxidant activity of phenolic compounds was correlated with their chemical structures ${ }^{12}$. In general, free radical scavenging and antioxidant activity of phenolic compounds mainly depend on the number and position of hydrogen-donating hydroxyl groups on the aromatic ring of the phenolic molecules, and is also affected by other factors, such as glycosylation of aglycones, or other H-donating groups $(-\mathrm{NH},-\mathrm{SH})$. Flavonoid compounds are important constituent of the phenolic families present in food stuffs and nutraceutical products. Flavone C-glucoside compounds of common herbs have important antibacterial activities. Some phenolic compounds for example, flavonoids such as quercetin, myricetin, and kaempferol, containing multiple hydroxyl groups had higher antioxidant activity. In this study, the ethyl acetate fraction showed the lower total polyphenol content and antioxidant activity than the methanol extract, but the flavonoid contents are higher than the methanol extract. Further studies are needed to identify the flavonoid compounds that play the role of antioxidant from the methanol extract and the ethyl acetate extract.

\section{Inhibition of cancer cell viability, proliferation,} and invasion

The effects of F-RV on cell viability were determined by the WST-1 assay in HCT-116 cells, which have a mutation of KRAS codon 13. Cells were treated 


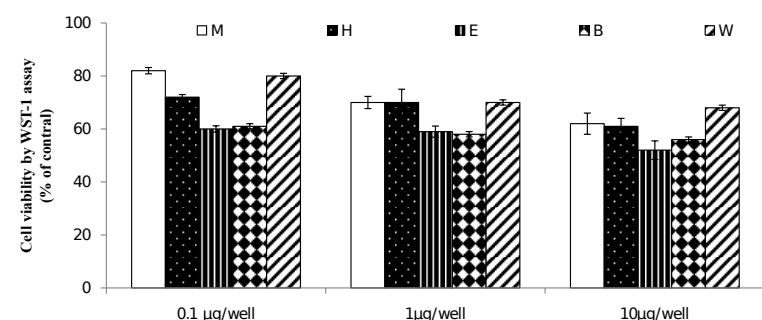

Fig. 2 Cell viability after treatment with F-RV extract.

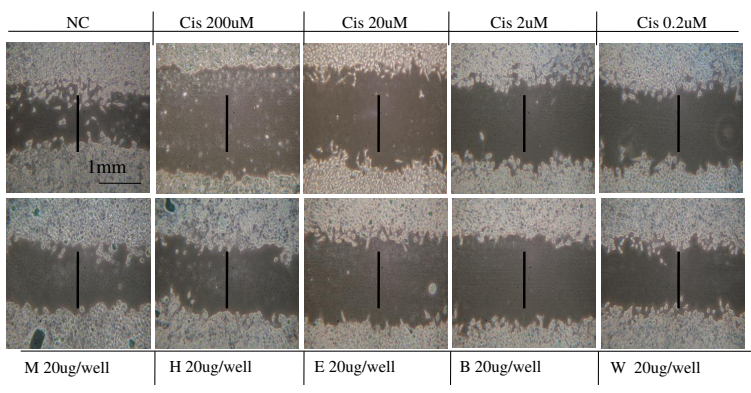

Fig. 3 Wound healing (magnification, 100×). Cisplatin (cis) at concentrations of 1,10 , and $100 \mu \mathrm{M}$ was used as the positive control.

with various concentrations of F-RV fractions in cell medium for $24 \mathrm{~h}$. The cell viability values indicated anticancer activity. Fig. 2 shows that the ethyl acetate fraction significantly inhibited the growth of cancer cells, compared with cisplatin. The results agree with those of a study using RV. The ethyl acetate fraction showed the lowest viability of HCT-116 cells $(53 \pm 7 \%)$ at a concentration of $10 \mu \mathrm{g} /$ well. In many studies, cell viability could be related to senescence and apoptosis. We monitored the ability of extract and fractions from F-RV to show cytotoxic activity in the cancer cell line. Inhibition of cancer cell growth and smaller cell size were observed, which are generally typical of apoptotic activation ${ }^{13,14}$. Wound healing was examined using HCT-116 cells. The wound area remaining at $24 \mathrm{~h}$ was taken as an index of wound healing (Fig. 3). Cells treated with 100, 10, 1, and $0.1 \mu \mathrm{M}$ cisplatin (positive control) showed a significantly greater wound area than in the negative control. Similar results were obtained with the F-RV extract and fractions. The composition and quality of herbal medicines are closely related as herbal drugs with different functions contain different active constituents ${ }^{15}$. Loganayaki et al reported that the yield of total phenolic compounds is dependent on the solvent. The recovery of polyphenolic compounds from plant materials is influenced by the solubility of
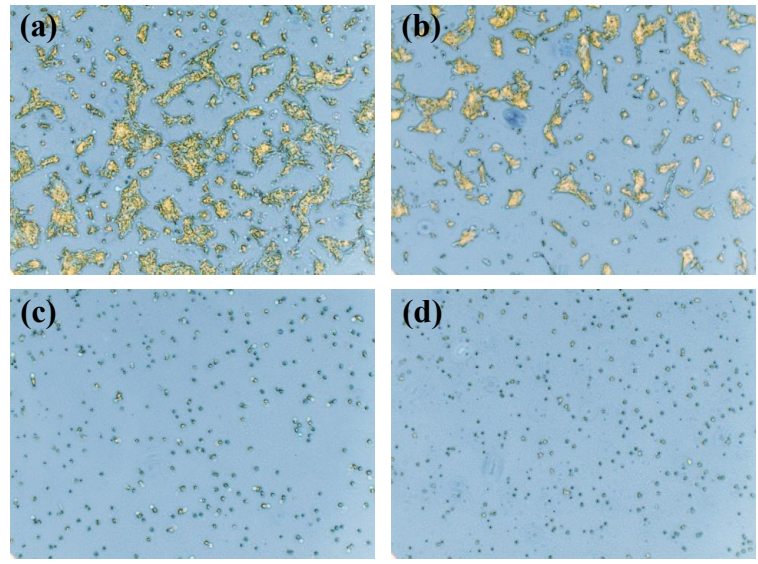

Fig. 4 Invasion assay: (a) normal; (b) extract; (c) F-RV ethyl acetate fraction (10 $\mu \mathrm{g} /$ well); (d) F-RV ethyl acetate fraction $(20 \mu \mathrm{g} /$ well) (magnification, $100 \times)$.

their in the extraction solvent used ${ }^{16}$. Other studies have also reported that the activity of extracts varies according to the solvent. In addition, the ethyl acetate fraction significantly inhibited the growth of cancer cells compared to other fractions. This was most probably due to the presence of flavonoid compounds, which were responsible for the strong anticancer activities. Flavonoids are a large group of polyphenolic compounds ${ }^{17}$ well-known as dietary antioxidants. These compounds have important effects on cancer chemoprevention and play a key role in reducing cancer cell proliferation ${ }^{18}$. Our study shows that F-RV has an inhibitory effect on cell proliferation and can induce apoptosis of the HCT116 cancer cell line (Fig. 4 and Fig. 5). These results suggest that F-RV should be useful for treatment of human cancers. Anti-cancer activity is significantly associated with total flavonoid content ${ }^{19}$, and some studies have shown cell damage activity of specific flavonoid compounds ${ }^{20,21}$.

\section{F-RV induced senescence, apoptosis, and hedgehog pathway}

Senescence and apoptosis occurred in HCT-116 cells treated for $24 \mathrm{~h}$ (Figs. 6-8). We also found that treatment with SMO siRNA for $4 \mathrm{~h}$ modulated hedgehog downstream signals in HCT-116 cells, which is consistent with the suggestion that F-RVactivated signalling could contribute to activation of an SMO inhibitor. In some studies, the expression of hedgehog pathway-related signalling molecules was explored for several cell lines. Although our results are limited to the HCT-116 cell line, F-RV can inhibit the proliferation of HCT-116 cell line by inhibiting 

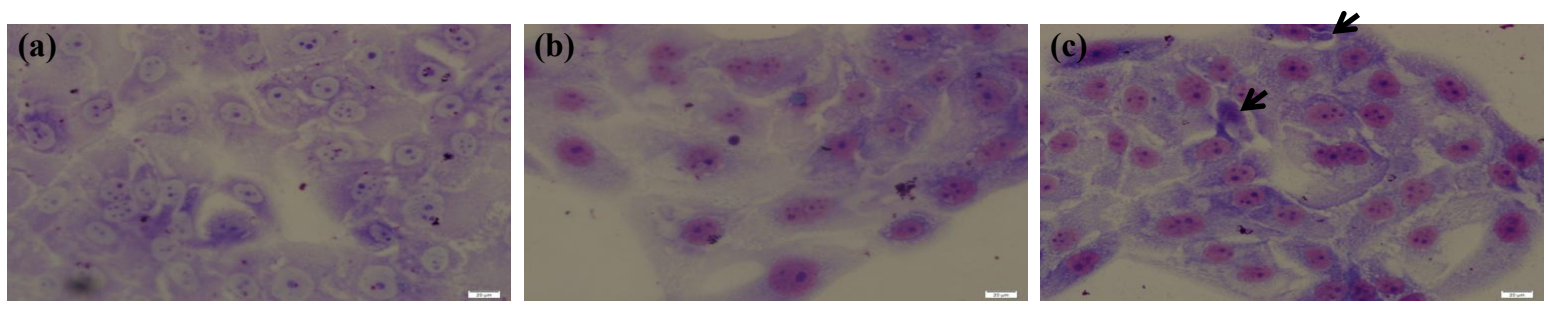

Fig. 5 Apoptotic body induced by the F-RV ethyl acetate fraction (magnification, 400×).
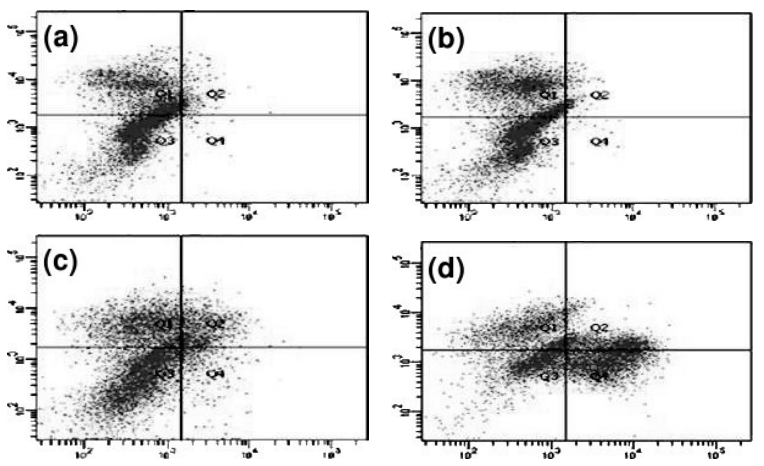

Fig. 6 Under identical conditions for FACS analysis, the percentage of apoptotic cells was expressed as the sum of Q2 (late state of apoptosis) and Q4 (early state of apoptosis); (a) control, (b) $1 \mu \mathrm{g} / \mathrm{ml}$, (c) $5 \mu \mathrm{g} / \mathrm{ml}$, (d) $10 \mu \mathrm{g} / \mathrm{ml}$.

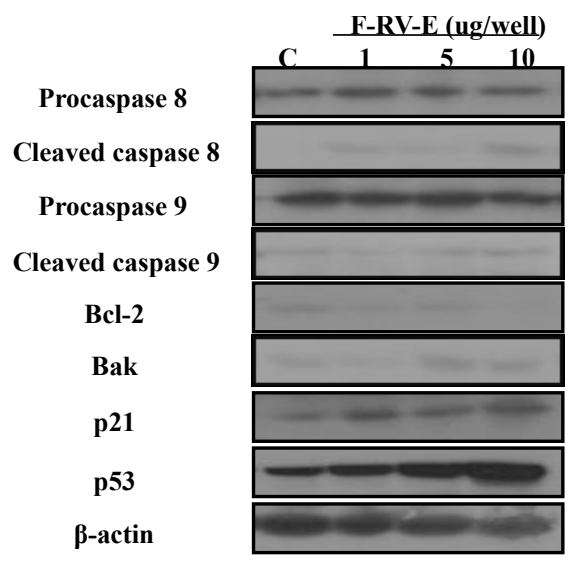

Fig. 7 Western blot of apoptosis and senescence.

hedgehog signalling pathway. Moreover, the study showed that F-RV inhibited the expression of Bcl-2 and promoted the expression of Bax, and induced the cleaved caspase-8 formation. Moreover, cellular senescence was associated with arrested growth and modified phenotype in culture. That phenotype modification was a change in the secreted cytokines, which was a senescence-associated change in HCT-

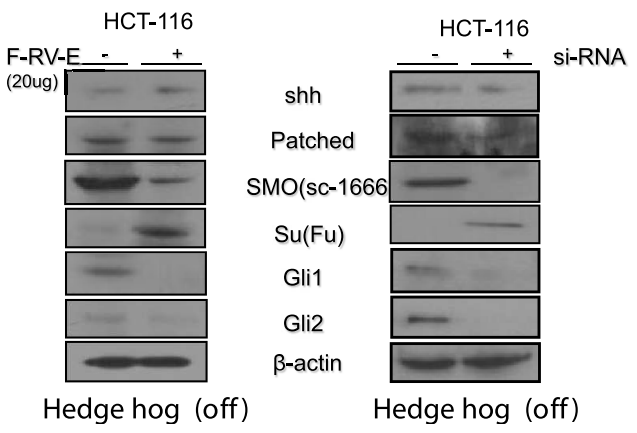

Fig. 8 Western blot of hedgehog signal pathway.

116 cells attributable to F-RV. There have been few studies of the hedgehog pathway inhibitory effect.

\section{F-RV induced cytokine change in whole cell lysate}

Our results suggest that cytokines interact with F-RV in HCT-116 cells, and affect the interaction of other response signals. These results showed that transforming growth factor $\beta$ (TGF- $\beta$ ) was up-regulated in whole cell lysate. Many studies have shown that TGF- $\beta$ up-regulation prevents phosphorylation of pRB. The loss of phosphorylated pRB mediates progression to cell cycle arrest, together with deregulation of cyclins and CDKs. However, we did not examine pRB, cyclins, or CDKs.

\section{Conclusion}

Clearly, our results show that F-RV has antioxidant and anticancer properties and has the ability to induce senescence or apoptosis and inhibits the hedgehog pathway. $R$. verniciflua has very limited use as a medicine or foodstuff. A fermenting biological system however can detoxify RV by removing the allergen, allowing the use of F-RV as a bioactive food and for the development as an anticancer drug.

Declarations: Myeong-ok Kim and Jinfeng Yang contributed equally to this work. 
Acknowledgements: This study was supported by the Kangwon National University and Cooperative Research Programme for Agriculture Science and Technology Development (Project NO. PJ009859) Rural Development Administration and gratitude to the Brian Pool (Konkuk University), Republic of Korea.

\section{REFERENCES}

1. Jang HS, Kook SH, Son YO, Kim JG, Jeon YM, Jang YS, Choi KC, Kim J, et al (2005) Flavonoids purified from Rhus verniciflua Stokes actively inhibit cell growth and induce apoptosis in human osteosarcoma cells. Biochim Biophys Acta Gen Subj 1726, 309-16.

2. Lee JC, Lee KY, Kim J, Na CS, Jung NC, Chung GH, Jang YS (2004) Extract from Rhus verniciflua Stokes is capable of inhibiting the growth of human lymphoma cells. Food Chem Toxicol 42, 1383-8.

3. Niimura N (2009) Determination of the type of lacquer on East Asian lacquer ware. Int J Mass Spectrom 284, 93-7.

4. Park KY, Jung GO, Lee KT, Choi J, Choi MY, Kim GT, Jung HJ, Park HJ (2004) Antimutagenic activity of flavonoids from the heartwood of Rhus verniciflua. $J$ Ethnopharmacol 90, 73-9.

5. Kim J, Kwon Y, Chun W, Kim T, Sun J, Yu C, Kim M (2010) Rhus verniciflua Stokes flavonoid extracts have anti-oxidant, anti-microbial and $\alpha$-glucosidase inhibitory effect. Food Chem 120, 539-43.

6. Lee JH, Lee HJ, Lee HJ, Choi WC, Yoon SW, Ko SG, Ahn KS, Choi SH, et al (2009) Rhus verniciflua Stokes prevents cisplatin-induced cytotoxicity and reactive oxygen species production in MDCK-I renal cells and intact mice. Phytomedicine 16, 188-97.

7. Reynertson KA, Basile MJ, Kenelly EJ (2005) Antioxidant potential of seven Myrtaceous fruits. Ethnobot Res Appl 3, 25-35.

8. Rosana C, Jorg G, Indira BP, Romina P, David C (2010) Antioxidant compounds and antioxidant capacity of Peruvian camu camu (Myrciaria dubia (H.B.K.) McVaugh) fruit at different maturity stages. Food Chem 120, 1019-24.

9. Berker KI, Güçlü K, Tor İ, Apak R (2007) Comparative evaluation of Fe(III) reducing power-based antioxidant capacity assays in the presence of phenanthroline, batho-phenanthroline, tripyridyltriazine (FRAP), and ferricyanide reagents. Talanta $\mathbf{7 2}$, 1157-65.

10. Kumar V, Rani A, Dixit AK, Pratap D, Bhatnagar D (2010) A comparative assessment of total phenolic content, ferric reducing-anti-oxidative power, free radical scavenging activity, vitamin $\mathrm{C}$ and isoflavones content in soybean with varying seed coat colour. Food Res Int 43, 323-8.

11. Shen Y, Jin L, Xiao P, Lu Y, Bao J (2009) Total phenolics, flavonoids, antioxidant capacity in rice grain and their relations to grain color, size and weight. $J$ Cereal Sci 49, 106-11.

12. Lien EJ, Ren SJ, Bui HYH, Wang RB (1999) Quantitative structure-activity relationship analysis of phenolic antioxidants. Free Radic Biol Med 26, 285-94.

13. Paul S, Mandal SK, Bhattacharyya SS, Boujedaini N, Khuda-Bukhsh AR (2010) In vitro and in vivo studies demonstrate anticancer property of root extract of Polygala senega. J Acupunct Meridian Stud 3, 188-96.

14. Wang X, Yuan S, Wang J, Lin P, Liu G, Lu Y, Zhang J, Wang W, et al (2006) Anticancer activity of litchi fruit pericarp extract against human breast cancer in vitro and in vivo. Toxicol Appl Pharmacol 215, 168-78.

15. Chen G, Zhang L, Zhu Y (2006) Determination of glycosides and sugars in Moutan Cortex by capillary electrophoresis with electrochemical detection. $J$ Pharmaceut Biomed Anal 41, 129-34.

16. Loganayaki N, Rajendrakumaran D, Manian S (2010) Antioxidant capacity and phenolic content of different solvent extracts from banana (Musa paradisiaca) and mustai (Rivea hypocrateriformis). Food Sci Biotechnol 19, 1251-8.

17. Cai Q, Rahn RO, Zhang R (1997) Dietary flavonoids, quercetin, luteolin and genistein, reduce oxidative DNA damage and lipid peroxidation and quench free radicals. Canc Lett 119, 99-107.

18. Sergedienè E, Jönsson K, Szymusiak H, Tyrakowska B, Rietjens IMCM, Čènas N (1999) Pro-oxidant toxicity of polyphenolic antioxidants to HL-60 cells: description of quantitative structure activity relationships. FEBS Lett 462, 392-6.

19. Sarin JPS, Singh S, Garg HS, Khanna NM, Dhar MM (1976) A flavonol glycoside with anticancer activity from Tephrosia candida. Phytochemistry 15, 232-4.

20. Li F, Wang F, Yu F, Fang Y, Xin Z, Yang F, Xu J, Zhao $\mathrm{L}, \mathrm{Hu} \mathrm{Q}$ (2008) In vitro antioxidant and anticancer activities of ethanolic extract of selenium-enriched green tea. Food Chem 111, 165-70.

21. Shin JS, Park YM, Choi JH, Park HJ, Shin MC, Lee YS, Lee KT (2010) Sulfuretin isolated from heartwood of Rhus verniciflua inhibits LPS-induced inducible nitric oxide synthase, cyclooxygenase-2, and pro-inflammatory cytokines expression via the down-regulation of NF- $\mathrm{BB}$ in RAW 264.7 murine macrophage cells. Int Immunopharmacol 10, 943-50. 